\title{
COSTAL MALFORMATION RELATED TO THORACOLUMBAR SCOLIOSIS IN ADOLESCENTS - CASE REPORT
}

\author{
MALFORMAÇÃO COSTAL RELACIONADA À ESCOLIOSE TORACOLOMBAR EM \\ ADOLESCENTE - RELATO DE CASO \\ MALFORMACIÓN COSTAL RELACIONADA CON LA ESCOLIOSIS TORACOLUMBAR EN \\ ADOLESCENTES - RELATO DE CASO \\ Nilza Nascimento Guimarāes' ${ }^{1}$, Júlio Cesar Caldas Pinheiro², Ubiratan Maia Rodrigues de Vasconcelos², Carolina Rodrigues de Mendonça ${ }^{1}$ \\ 1. Universidade Federal de Goiás, Goiânia, GO, Brazil. \\ 2. Centro de Estudos em Enfermagem e Nutrição (CEEN), Goiânia, GO, Brazil.
}

\begin{abstract}
Congenital scoliosis associated with costal malformation is well known. However, there are no reports of idiopathic scoliosis associated with the fusion of the costal arcs in the literature. This report describes a case of idiopathic scoliosis with fusion of the 1st and 2nd costal arches in a female patient and reports changes in the deformity due to scoliosis because of the treatment. The analysis was performed from a morphological and clinical point of view, and by complementary tests. Radiographs and CT scans were obtained and evaluated from the first consultation in 2012 and during the period in which the patient was followed in a private clinic, until the stabilization of the condition, in 2014. The evolution was favorable with the use of a Milwaukee vest and there was improvement of the clinical picture after the skeletal maturity, and the angle of lateral curvature, measured by the Cobb method, initially of 20 degrees, was reduced and stabilized in nine degrees, measure which is currently maintained. The analysis showed concomitant pathologies, and the fusion of costal arches did not influence the spine deformity, since there was regression with the clinical treatment. This evolution leads us to conclude that adolescent idiopathic scoliosis should be imputed as the sole responsible for the clinical picture of the patient, and that the fusion of the costal arches does not interfere with the biomechanics of the spine. Level of Evidence: IV. Type of study: Case series.
\end{abstract}

Keywords: Ribs; Adolescent medicine; Scoliosis.

\section{RESUMO}

A escoliose congênita associada à malformação costal é bem conhecida. Porém, não existe na literatura relatos de escoliose idiopática associada à fusão dos arcos costais. Este relato descreve um caso de escoliose idiopática com a fusão do $1^{\circ}$ e $2^{\circ}$ arcos costais em paciente do sexo feminino, e relata modificações da deformidade por escoliose em decorrência do tratamento. A análise foi realizada do ponto de vista morfológico, clínico e por exames complementares. Foram avaliadas radiografias e tomografias obtidas desde a primeira consulta, em 2012, e durante o período em que a mesma foi acompanhada em uma clínica particular, até a estabilização do quadro em 2014 . A evolução foi favorável com uso de colete de Milwaukee e houve melhora do quadro clínico após maturidade esquelética, sendo que o ângulo de curvatura lateral, aferido pelo método de Cobb, inicialmente de 20 graus, reduziu e se estabilizou em nove graus, sendo que esta medida se mantém atualmente. Pela análise realizada, houve uma concomitância de patologias, sendo que a fusão de arcos costais não influenciou na deformidade da coluna, uma vez que a mesma regrediu com o tratamento clínico. Esta evolução nos leva a concluir que a escoliose idiopática da adolescente deve ser imputada como a única responsável pelo quadro clínico da paciente, e que a fusão dos arcos costais não interfere na biomecânica da coluna vertebral. Nível de Evidência: IV. Tipo de estudo: Série de caso.

Descritores: Costelas; Medicina do adolescente; Escoliose.

\section{RESUMEN}

La escoliosis congénita asociada a la malformación costal es bien conocida. Sin embargo, no existen relatos de escoliosis idiopática asociada a la fusión de los arcos costales en la literatura. Este relato describe un caso de escoliosis idiopática con la fusión del primer y segundo arco costal en paciente del sexo femenino y relata modificaciones de la deformidad por escoliosis como consecuencia del tratamiento. El análisis fue realizado desde el punto de vista morfológico y clínico y por exámenes complementarios. Se evaluaron las radiografías y tomografías obtenidas en la primera consulta, en 2012 y durante el período en el que la paciente fue acompañada en una clínica particular, hasta la estabilización del cuadro, en 2014. La evolución fue favorable con uso de chaleco de Milwaukee y hubo una mejora del cuadro clínico después de la madurez esquelética, siendo que el ángulo de curvatura lateral, medido por el método de Cobb, inicialmente de 20 grados, se redujo y se estabilizó en nueve grados, lo que se mantiene actualmente. Por el análisis realizado, hubo concomitancia de patologías, siendo que la fusión de arcos costales no influenció la deformidad de la columna, una vez que hubo regresión con el tratamiento clínico. Esta evolución nos lleva a concluir que la escoliosis idiopática de esta adolescente debe ser imputada como la única responsable del cuadro clínico de la paciente, y que la fusión de los arcos costales no interfiere en la biomecánica de la columna vertebral. Nivel de Evidencia: IV. Tipo de estudio: Serie de caso.

Descriptores: Costillas; Medicina del Adolescente; Escoliosis. 


\section{INTRODUCTION}

Congenital scoliosis is a lateral deformity of the spine with a disruption of the sagittal profile caused by malformations of the vertebrae and the ribs. ${ }^{1}$ Patients with congenital scoliosis often have other associated abnormalities. Sometimes, the fusion or absence of ribs can be observed together with spinal abnormalities, since the ribs are formed in close association with the vertebrae. When the number of ribs on the right and left sides do not match, vertebral abnormalities should be suspected. ${ }^{2}$

Congenital scoliosis associated with costal malformation is well known. However, there are no reports of adolescent idiopathic scoliosis associated with fusion of the costal arcs in the literature. Few studies report the long-term results of surgical techniques on the natural progression of scoliosis. Similarly, few studies about the influence of conservative treatment have been published and more research is necessary to document when a conservative approach is necessary. ${ }^{3-5}$ The objective of this study is to report a case of congenital scoliosis with costal arc fusion in a female patient and the anatomical modifications of the scoliotic deformity resulting from conservative treatment

\section{CASE REPORT}

In April 2012, a 13-year-old female patient arrived at the emergency room of a private clinic complaining of pain in the lumbar and thoracic spines, radiating to the lower limbs and worsening with physical exertion. After consultation with the orthopedist, chest radiography and tomography were requested for the purpose of diagnostic elucidation. The clinical examination revealed gibbousness in the dorsal region on the right and in the lumbar region on the left, with asymmetry of the trunk angle, asymmetry of the shoulders, shortening of the ischiotibial muscles, and asymmetry of the breasts. There was a correction of the curvature of the deformity during the examinations of inclination.

The radiographic evaluation was performed by the Cobb technique, using anteroposterior and lateral view radiographs of the first sacral vertebra and above. The angle formed by perpendiculars drawn between the lines that touch the upper and lower surfaces of the vertebrae, which are more directed towards the center of the concavity, was measured. Additionally, bone growth potential was analyzed using the Risser method.

Upon radiographic examination of the spine in the anteroposterior view, the patient presented 20 degrees of curvature as measured from L2 to T6 using the Cobb method (Figure 1A). The tomographic examination showed fusion of the first and second right costal arcs (Figure 1B). The potential bone growth of the patient was classified as stage two using the Risser method.

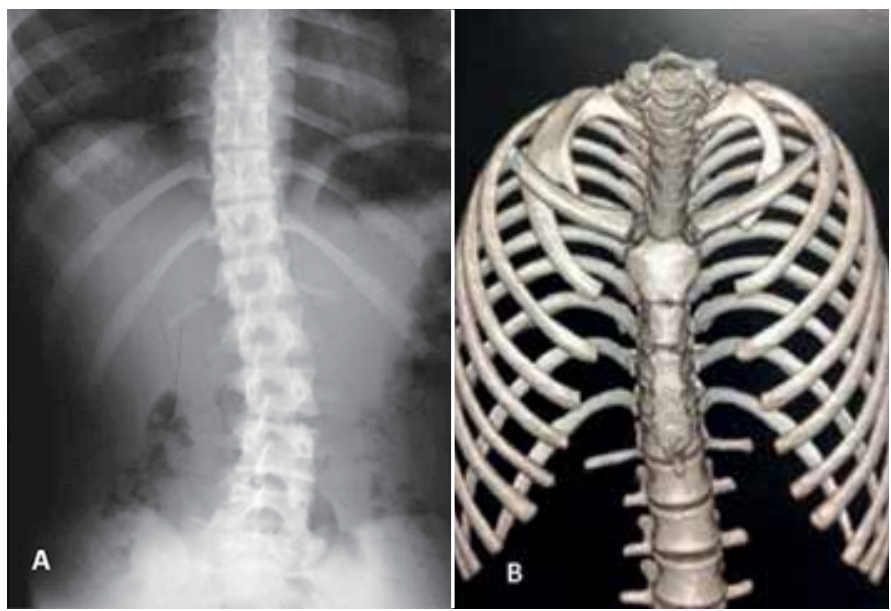

Figure 1. A) Anteroposterior view X-ray of the spine, in which the angle of lateral curvature was measured as 20 degrees using the Cobb method. B) Computed tomography showing the fusion of the 1st and 2nd right costal arcs
In 2012, the Milwaukee vest was indicated for initial therapy, with weekly follow-ups in which new clinical and radiographic exams were performed. In the consultation on October 8, 2013, a reduction in the pathological curvature was observed, with the Cobb angle from L2 to T6 measuring 11 degrees (Figure 2A).

The patient used the vest until March 2014, when the Cobb angle was measured with a reduction to nine degrees, and she reported improved pain. On this occasion, the Risser measurement was taken, showing stage four, and weaning from the vest was selected as the therapeutic option.

After treatment with the Milwaukee vest, the patient had no complaints of pain and the Cobb angle was stabilized at nine degrees (Figure 2B). The patient is participating in water aerobics three times a week regularly to maintain posture. Data collection was performed by analyzing the medical records from the previous five years, after the Informed Consent Form was signed by the patient's legal guardian.

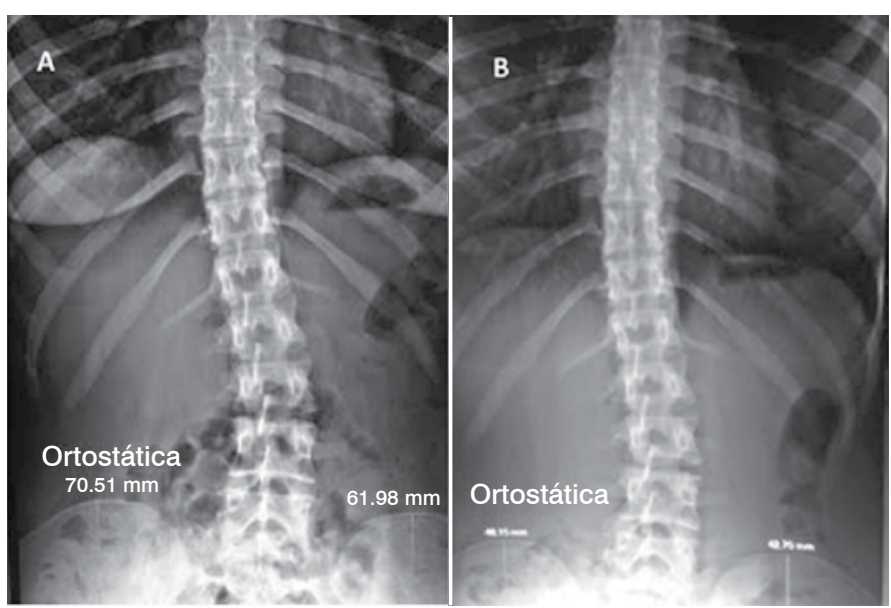

Figure 2. X-ray of the patient for measurement of the angle using the Cobb method - Cobb angle measuring 11 degrees in October, 2013. B) X-ray of the patient for measurement of the angle using the Cobb method - Cobb angle measuring nine degrees in March, 2014

\section{DISCUSSION}

Congenital scoliosis is a failure in vertebral formation, segmentation, or a combination of both with abnormal vertebral formation during the first four to six weeks of pregnancy. It represents a wide range of pathologies from simple and stable hemivertebra to complex progressive medullary deformity with abnormalities in the chest wall, and cardiac, renal, and neural abnormalities. ${ }^{6}$

Untreated growing patients with congenital scoliosis and fused ribs can develop thoracic insufficiency syndrome in serious cases. ${ }^{7}$ Congenital scoliosis with associated rib fusions, thoracic syndrome, and hypoplastic thorax can create progressive three-dimensional deformity of the chest, inhibiting normal lung growth and respiratory function, leading to respiratory failure. ${ }^{8}$

Adolescent Idiopathic Scoliosis (AIS) is a structured lateral curve of the spine of undetermined cause that occurs between 10 and 18 years of age and is not associated with fusion of the costal arcs. ${ }^{9}$ Although this report describes fusion of the costal arcs in a patient with AIS, the fusion did not influence the spinal deformity and did not harm the patient since she did not present painful symptoms in the right upper limbs or compromise respiratory function.

The treatment decision for any condition is based on the premise that the treatment will change the natural history of the pathology. ${ }^{9}$ Typically, the treatment of choice for young patients with congenital scoliosis (before age three) is early surgical intervention. ${ }^{1}$ In patients with AIS with serious rigid curves, the treatment of choice is also surgical intervention. ${ }^{10}$ Patients with segmentation failures and severe rigid curves generally require surgical intervention such as rib osteotomy to increase the flexibility of the scoliotic curvature. 5,6,10 Complex unilateral deformities in particular significantly compromise the outcomes of curve correction surgery in congenital scoliosis. ${ }^{5}$ 
It is difficult to predict the final outcome of surgical treatment in patients with congenital scoliosis, ${ }^{1}$ though there is no evidence of progression in the long term. ${ }^{6}$ There are authors who consider it prudent to advocate conservative management before considering spine surgery. ${ }^{1}$ Comparatively, many patients with idiopathic scoliosis are able to avoid spine surgery with the application of reinforcement technology, such as the Milwaukee vest. ${ }^{1,9}$

\section{CONCLUSIONS}

The case reported describes the unique clinical situation of a classic profile of idiopathic scoliosis associated with congenital fusion of two costal arcs. The evolution was favorable with the use of a Milwaukee vest and the clinical profile improved after skeletal maturity. The fusion of the costal arcs did not influence the spinal deformity, since it regressed with clinical treatment. This evolution led us to conclude that adolescent idiopathic scoliosis should be imputed as solely responsible for the patient's clinical profile and that, in this case, fusion of the costal arcs did not interfere in the biomechanics of the spine.

All authors declare no potential conflict of interest related to this article.

CONTRIBUTION OF THE AUTHORS: Each author made significant individual contributions to this manuscript. JCCP(0000-0002-4739-2131)* and UMRV (0000-0002-2470-7575)* were the principal contributors to data collection and the writing of the manuscript. NNG(0000-0002-4755-5682)* and CRM(0000-0002-4755-5682)* performed the bibliographical research and reviewed the manuscript. *ORCID (Open Researcher and Contributor ID).

\section{REFERENCES}

1. Weiss HR, Moramarco M. Congenital Scoliosis (Mini-review). Curr Pediatr Rev. 2016;12(1):43-7.

2. Debnath UK, Goel V, Harshavardhana N, Webb JK. Congenital scoliosis-Quo vadis? Indian J Orthop. 2010:44(2):137-47.

3. Erkula G, Sponseller PD, Kiter AE. Rib deformity in scoliosis. Eur Spine J. 2003;12(3):281-7.

4. Ameri $E$, Fouladi DF, Ghandhari $H$, VahidTari $H$, Safari MB. The Effect of Concomitant Rib Deformity in Congenital Scoliosis on Spinal Curve Correction After Segmental Pedicle Screw Instrumentation. Clin Spine Surg. 2017;30(4):E485-E90.

5. Kaspiris A, Grivas TB, Weiss HR, Turnbull D. Surgical and conservative treatment of patients with congenital scoliosis: alpha search for long-term results. Scoliosis. 2011;6(12):12-29.

6. Pahys JM, Guille JT. What's New in Congenital Scoliosis? J Pediatr Orthop. 2016;22.
7. Dayer R, Ceroni D, Lascombes P. Treatment of congenital thoracic scoliosis with associated rib fusions using VEPTR expansion thoracostomy: a surgical technique. Eur Spine J. 2014;23(4):424-31.

8. DiFazio R, Tubman D. Congenital Scoliosis With Associated Rib Fusions: Nursing Care of Patients Following VEPTR Insertion. Orthop Nurs. 2010;29(1):4-8.

9. Lima JúniorPCD, PellegrinoL, CaffaroMFS, MevesR, Landim E, Avanzi O. Escoliose idiopática do adolescente (eia): perfil clínico e radiográfico da lista de espera para tratamento cirúrgico em hospital terciário de alta complexidade do Sistema Público de Saúde Brasileiro. Coluna/Columna. 2011;10(2):111-15.

10. Simões MS, de Abreu EV, Winkler BC. Osteotomias posteriores de três colunas para tratamento de cifose dorsal rígida-Série de casos. Rev Bras Ortop. 2017;52(2):189-96. 